\title{
The Impact of Energy Cooperation and the Role of the One Belt and Road Initiative in Revolutionizing the Geopolitics of Energy among Regional Economic Powers: An Analysis of Infrastructure Development and Project Management
}

\author{
Wu Hao $\mathbb{D}^{1},{ }^{1}$ Syed Mehmood Ali Shah, ${ }^{1}$ Ahsan Nawaz $\mathbb{D},{ }^{2}$ Ali Asad, ${ }^{3}$ Shahid Iqbal, \\ Hafiz Zahoor ${ }^{(D},{ }^{5}$ and Ahsen Maqsoom ${ }^{6}$ \\ ${ }^{1}$ Northeast Asian Research Centre, Jilin University, Changchun 130012, China \\ ${ }^{2}$ Institute of Construction Project Management, CCEA, Zhejiang University, Hangzhou 310058, China \\ ${ }^{3}$ School of Management, Shenzhen University, Shenzhen, Guangdong 518060, China \\ ${ }^{4}$ Management Studies Department, Bahria University, Islamabad, Pakistan \\ ${ }^{5}$ Construction Engineering \& Management Department, National University of Sciences and Technology, Risalpur Campus, \\ KPK 24080, Pakistan \\ ${ }^{6}$ Civil Engineering Department, COMSATS University Islamabad, Wah Campus, Wah 47040, Pakistan
}

Correspondence should be addressed to Wu Hao; wuh@jlu.edu.cn and Ahsan Nawaz; ahsanklasra@zju.edu.cn

Received 3 September 2020; Revised 10 September 2020; Accepted 15 September 2020; Published 12 October 2020

Academic Editor: M. A. Mostafa Khater

Copyright $@ 2020 \mathrm{Wu}$ Hao et al. This is an open access article distributed under the Creative Commons Attribution License, which permits unrestricted use, distribution, and reproduction in any medium, provided the original work is properly cited.

\begin{abstract}
This paper examines how the latest mega plan and the Belt and Road Initiative (BRI) will impact the geopolitics of energy and infrastructural development. With a massive change in the supply and demand of global energy and its infrastructure, the transition of international energy order is in the making. While the US is going towards a more isolationist path from its traditional superpower role, there are rising economies such as China, India, Japan, and Russia which are undoubtedly playing a vital role in the geopolitical stage and the other development endeavors. Several regions such as Central Asia, the Arctic, Eastern Mediterranean, and the South China Sea are offering substantial natural gas and oil reserves and drawing global attention to develop energy cooperation. This situation is profoundly influencing the transition of energy order. In this transition, BRI is supposed to play an important role. As a mega development strategy with a robust geostrategic dimension, it purposes to advocate interconnectivity collaboration in framework, exchange, and advancement among the partaking nations. This super arrangement offers a lot of ventures, foundation developments, and modern reconciliation in the energy sector. The country is trying to establish a multilateral platform for endorsing and shielding energy cooperation under BRI. This paper, therefore, attempts to observe how this mega plan will contribute to reshaping the existing energy order as well as the geopolitics of energy with motivation on multifaceted energy collaboration.
\end{abstract}

\section{Introduction}

BRI, incomparable in size and capacity, is offering massive investments in its member countries across Asia, Europe, and Africa. With its core leitmotif-connectivity and infrastructure development, this mega plan is marching high with its proposed and already started infrastructural projects across these three continents [1, 2]. While assessing its importance, scholars like Parag Khanna, in his latest book, significantly mentioned the role of BRI in the rise of Asia. He even said that the date of Asian-led world order would be remembered when 68 countries, mirroring two-thirds of the world's populace, assembled in Beijing to attend the first BRI summit in 2017 [3]. This gathering symbolizes the most extensive coordinated investment plan for interconnectivity and infrastructural development in human history [4]. 
Having such substantial geopolitical and geoeconomic dimensions, BRI promises to invest around US\$ 1 trillion in Asia, Europe, and Africa for implementing a series of development projects [5].

At first, the energy was not officially mentioned in its five primary territories-foundation, arrangement, money, exchange, and culture. However, the issue of energy security is diligently linked to BRI member countries and China. Therefore, this issue has been included in the Vision and Actions on Jointly Building Silk Road Economic Belt and 21st Century Maritime Silk Road. It is a dream archive that was given in March 2015, two years after the declaration of this vital plan [6-9]. After that, in May 2015, another vision document was released, which was thoroughly dedicated to the issue of energy cooperation under BRI. It is a dream archive that was given in May 2015, two years after the declaration of this uber plan [10]. A revised version of "Vision and Actions on Energy Cooperation" was released in May 2017. In this latest document, seven critical areas of energy cooperation through the BRI were identified [11]. These are unimpeded trade, policy coordination, energy investment cooperation, energy production capacity cooperation, energy infrastructure connectivity [12], sustainable energy for all, and better governance structure.

A number of bilateral and multilateral collaboration opportunities for progressing in energy cooperation were suggested in the latest document [13]. Of them, the formation of a Belt and Road Energy Cooperation Club was a remarkable proposal [12]. Based on that proposal, the Belt and Road Energy Partnership (BREP) was launched in the second Belt, and Road Forum held on April 25-27, 2019 [14]. BREP is designed for practicing the doctrine of collaboration and shared benefit, encouraging conjointly valuable energy collaboration, supporting the countries and regions to mutually resolve complications hindering energy growth, attaining shared growth and prosperity, and making positive offerings to build a community with a shared future for humanity $[15,16]$. During the consultation, a document on mutual aid principles and concrete actions of BREP was released [10]. According to the document, partaking states would reinforce infrastructure connectivity, boost energy investment, and uphold cooperation in clean energy, energy efficacy, capacity building, and personnel training. Although the BREP platform is newly launched, China has already become engaged intensely with several energy infrastructure projects since the launching of BRI [17]. With BRI, President $\mathrm{Xi}$ is moving with more confidence, China-centric tactic of ruthless for achievement, in distinction with the previous president Deng Xiaoping's maxim of keeping a stumpy nature [14]. Particularly, in the energy sector, China has been focusing on the strategy of "going out" to invest overseas. After the launching of BRI, the Chinese aspiration of deepening itself in international energy cooperation at all levels became noticeable [18-20]. Through BRI energy projects, the country is now preparing to assimilate itself with a world energy system based on win-win cooperation. While strengthening comprehensive international cooperation on energy, China also aims to develop a shared global energy future through the BRI. Since its inception, BRI energy projects are continually achieving prolific results [16]. Energy projects like Yamal Energy project are one of the successful projects that are worth notable $[14,21]$. If the situation goes like this, then, China may become a noteworthy and proactive competitor in shaping global energy governance.

In the geopolitical lens, comprehensive energy projects and consolidated approach for energy cooperation among BRI countries bear significant importance in the geopolitics of energy [22]. In the 18th and 19th centuries, coal and steam power sped up the industrial revolution and shaped the geopolitics of those centuries [23]. Global control over coal production and trade was led by the British Empire during that century. After that, 20th-century geopolitics was all about control over the creation of and trade in oil [22]. America's hegemony started in that century by successfully proving its guardianship of the free flow of oil since the Arab oil embargo of 1973 [24]. Although the 21st century is still favoring the fossil fuel-coal, oil, and natural gas-that accounts for 80 percent of world energy [25], a gradual shift to investments in nuclear, hydro, and renewable energy sources is increasing [26]. The shale oil revolution in America and the transformation of natural gas into its liquefied form (LNG) are the striking features of the 21st century's energy geopolitics. With the shale revolution, there is a possibility that the US could become an energy exporter [24]. Although this situation will not diminish American interest in stabilizing oil prices in the global market, it will modify the nature of America's relationship with existing sellers and new buyers. In this context of changing energy order, China's BRI can be a game-changer [27]. Through the BRI, China is initiating alternative energy routes to safeguard the flow of fossil fuel for China and the BRI countries. Thus, avoiding reliance on the existing energy route, namely, the Strait of Malacca and the South China Sea, BRI countries can safely have their fossil fuel without facing any threat [28]. This situation signals the new energy order in the present century. Also, China has a prominent status in renewable energy technologies. Through the BRI, China has notable renewable energy projects which can support producing renewable energy. In this backdrop, it can be understood that BRI has all the potential to play a significant role in shaping the 21st century's energy geopolitics [6, 23, 28, 29]. A glimpse of the different projects under BRI including energy projects is shown in Figure 1.

This paper, therefore, seeks to understand how BRI will be stimulating enormous energy benefits by expanding the weighbridge, choice, and impact of China's dynamism track. Through its advanced energy and infrastructure projects, BRI might be empowering Beijing to progressively silhouette the imminence of energy and infrastructure (transportation) reservation milieu across interior Eurasia and through the dynamic sea lanes of the Indo-Pacific. It may also enable BRI countries to be under the umbrella of energy and infrastructure cooperation mechanism that allows them to achieve maximum benefits without facing any significant threat. With discussion of the BRI of energy geopolitics and its impact on infrastructure and connectivity and economic growth, this paper also argues BRI's contribution to 


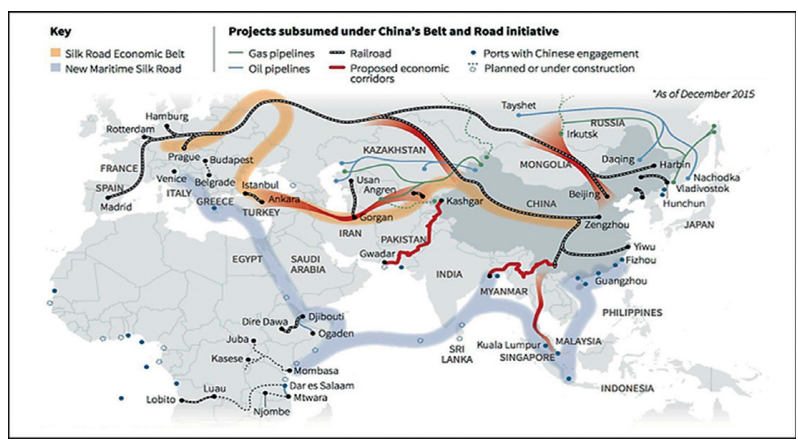

FigURE 1: BRI projects and region map [30].

changing nature of the existing energy order and the total impact of the multimodal impact of transport infrastructure on economic level that will gradually shape the future of energy and transport geopolitics. To understand this argument, the synergy between energy geopolitics, including infrastructure development and BRI, has been thoroughly discussed in the second section after the introduction. The third section depicts China's current energy and infrastructure projects under the BRI for strengthening energy and transport projects cooperation among BRI countries. The paper proceeds with analyzing the possible implications and influence of BRI's energy and transport on shaping the geopolitics of energy and infrastructural development. This discussion makes the fourth section of this paper. It concludes by echoing the broader context of its role in upholding energy cooperation and infrastructure development among BRI countries by shaping energy geopolitics and that ultimately paves the way for new energy and multimodal transport infrastructure order.

\section{Synergy between BRI, Geopolitics of Energy, and Infrastructure Development}

As per energy security perspective, China's mega plan BRI promises enormous contribution in forming an assimilated network of supplies and value chains in the energy and infrastructural development sector. Through BRI, China can finance energy schemes such as the development of onshore and offshore oil and gas fields, coal mines and coal-fired power plants, grid networks, and increasing renewable energy sources (RES) [31]. Encircling a number of economic corridors, transportation routes, and infrastructural Projects across 84 countries, this mega plan can be the most ambitious development project in history. It is a proactive strategy for China to grow and extend connections with the partner countries of BRI. An analysis of the financial connectivity with different financing companies and all BRI countries members is shown in Figure 2. The left-side pattern shows the average score from the period 2005-2007, and the right-side pattern shows the overall projects cost in USD (millions).

China has invested a huge amount in different countries in construction sector which consists of USD 253.8 billion as compared to the total cumulative of USD 420 billion since 2005. As up to 2025, China will move from construction development, energy, and heavy machinery to the more sophisticated industries of agriculture, chemicals, logistics, transport, real estate, and the metals. That would be called China's 13th five-year plan of 2025. A glimpse of 2025 targeted areas is mentioned in Figure 3.

China is investing almost in every area of the field to boost his economy in which BRI was one of his mega plans for his country's economic position.

China's growing reliance on seaborne energy trade specifies its quest for energy security [34]. This growing energy demand promotes the imperatives for its energy diversification strategy by diversifying energy import sources and transit routes, protecting its interests and rights over Sea Lanes of Communications (SLOCs) and developing the People's Liberation Army Navy's (PLAN) blue water capabilities $[10,35]$. Thus, from the perspective of China's energy security, the country's infrastructural projects for developing transit pipelines through the partner countries of BRI, constructing ports, and developing port facilities for the PLAN will be the essential structures of the 21st century Maritime Silk Road (MSR) of the BRI [19, 20, 36].

2.1. Energy Transition and Geopolitics. However, to understand the synergy between BRI and the geopolitics of energy, primarily, there is a need to understand the concept of energy geopolitics. Energy resources have an enormous impact on a state's national strategy and economic growth. Therefore, access to these or having sufficient of them is essential to ensure domestic and global security. Although classical geopolitics mainly refers to the military field, changes have started to take place in conceptualizing geopolitics by incorporating multidisciplinary approaches $[37,38]$. Energy is one such discipline that can influence a state's foreign policy. Keeping this in mind, Ioannis Vidakis and Georgis Baltos created the concept of "geoenergia" [32]. This concept is to comprehend the special effects of energy assets in political and economic systems, as well as in international dealings [12]. Although in the past, natural resources had a vital role in influencing international dealings, especially in the 18th and 19th centuries, that were the age of coal, the issue of energy geopolitics gained impetus after the 1990 s in the 20th century. Since that century, global natural resources, especially fossil fuels, started to become limited in the face of emergent world demand for energy [39]. Notably, 


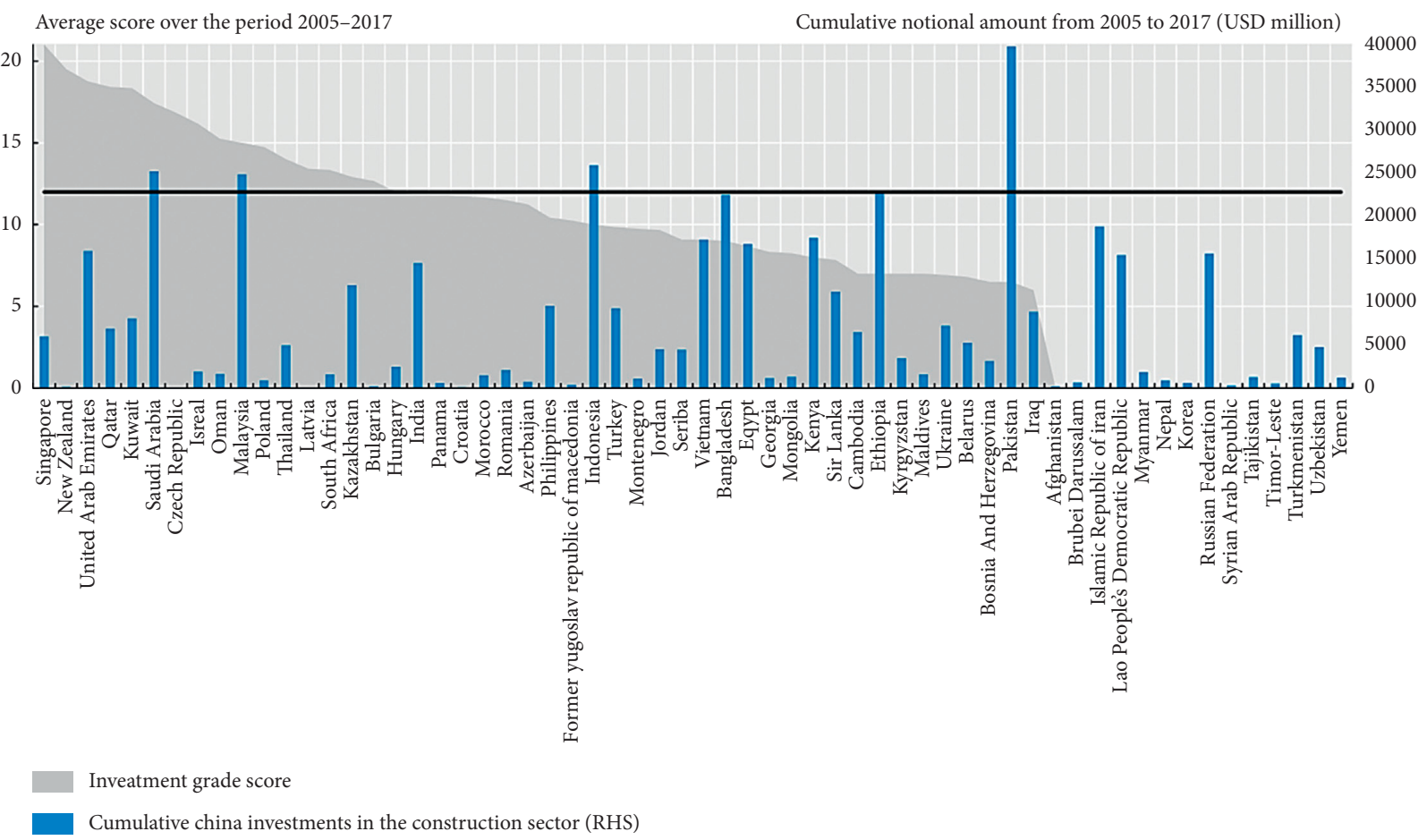

FIGURE 2: Investment of construction projects under BRI countries (credit rating score) [32].

the two oil emergencies of the 1970s publicized the degree of susceptibility and dependency on fossil fuels. From that time, classical studies on energy geopolitics started to gain attention [13]. The growth of energy and its renewable fastest-growing resources and the electrification are the major factors in the geopolitics of the energy nowadays with respect to the economic comparison and the growth statistics. A forecasted framework based on the data of shell sky scenario [40] is mentioned in Figure 4. It reflects the fossil fuels energy and the renewable energy till 2100.

A number of analyses were devoted to clarifying the concept of energy geopolitics. Philip Andrews-Speed stated that energy geopolitics could be referred to the study of national security and international politics in the perspective of the global energy scene. Therefore, the term "energy geopolitics" refers to the management of energy-related relationships that exist among states [41, 42]. It is one of the major elements in reshaping the geopolitics in the "environment and its sustainability, domestic politics in different states, the demography of the cities, urbanization and the involvement of the technology." In the mechanisism of perceiving a renewable energy potential, there is a need to uplift the solar and energy projects with the fossil fuel transitions to boost the energy infrastructure. The world potential with respect to energies projects is mentioned in Figures 5(a) and 5(b).

Although the most fundamental relationship occurs between the energy providers and consumers, a vital relationship can also take place between and among competing consumer countries and groups of consumer countries $[42,43]$. The same meaningful relationship can take shape between and among supplier countries or group of supplier countries as well. The energy transactions in different economies, according to fossil fuels importers and exporters, are grouped as shown in Figure 6.

2.2. Geopolitics and Its Effect on Different Countries. The relationships may occur, such as connections in one party or another can exploit its energy-related power to dominate other aspects of political or security relations with another country. Thus, the whole issue of energy geopolitics is intertwined with various dynamics of relationships between and among the energy suppliers and consumers and their relationships with other countries [43, 45]. Apart from an energy-related relationship that shapes energy geopolitics, Philip also addressed some critical factors of energy geopolitics. These are resource nationalism, a rise of national oil companies, instability in oil-producing regions due to domestic, regional and international factors, reserve depletion among traditional suppliers, and politics around SLOCs. However, the 21st century is experiencing a relative decline of US military capacity along with political deadlock at home. This situation has created uncertainty to the existing energy order. The situation has developed more bothersome subsequently, for example, Donald Trump's (United States President) allocation to his "America First" fustian [39]. Aside from President Donald Trump's isolationist activities, America's energy revolution has changed the existing scenario of world energy order. America made the global leader in energy production during President Obama's second term. After that, the US energy production has continued to grow nearly every year [16]. 


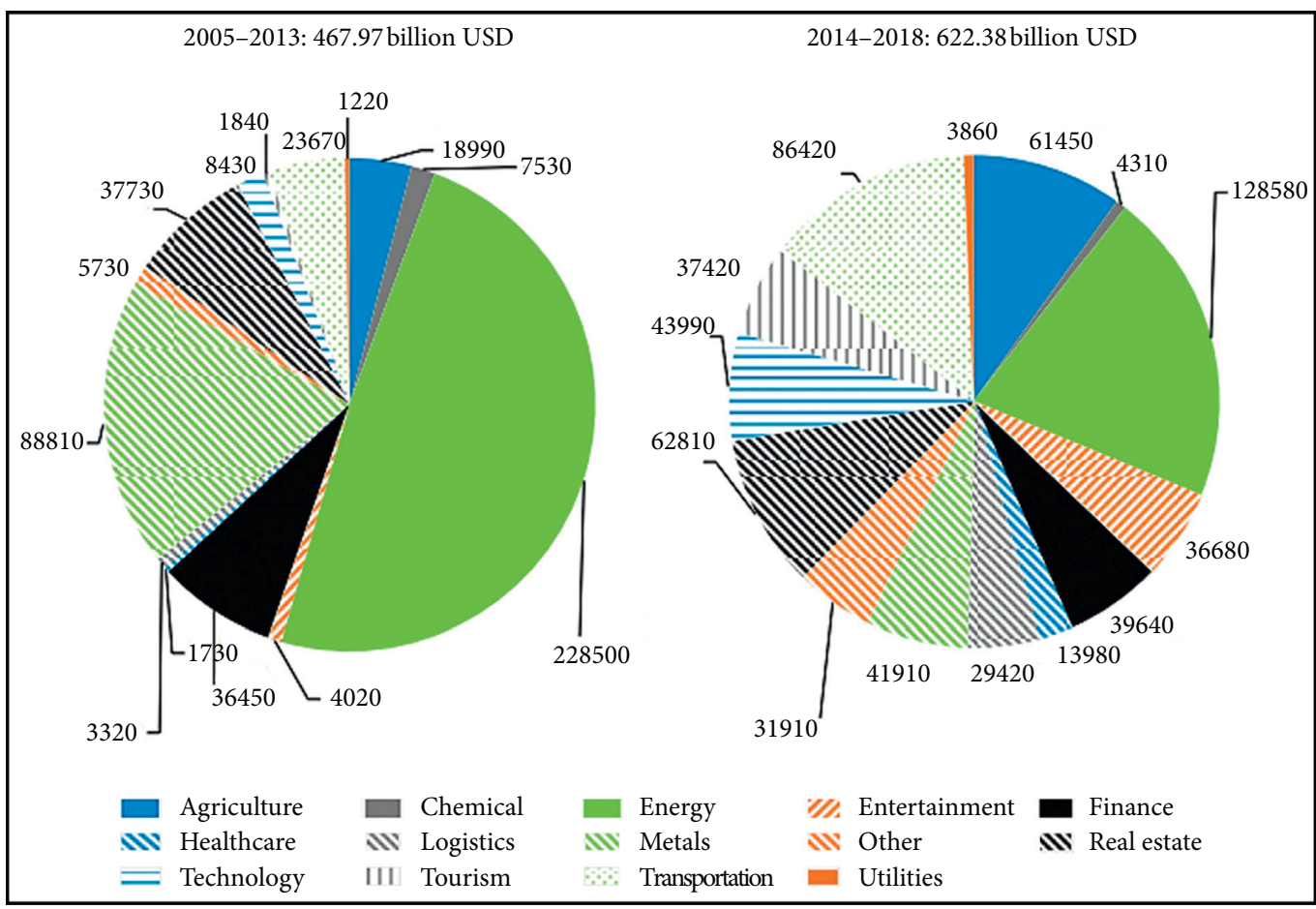

FIgURE 3: China investment in global economy (2005-2013 versus 2014-2018) [33].

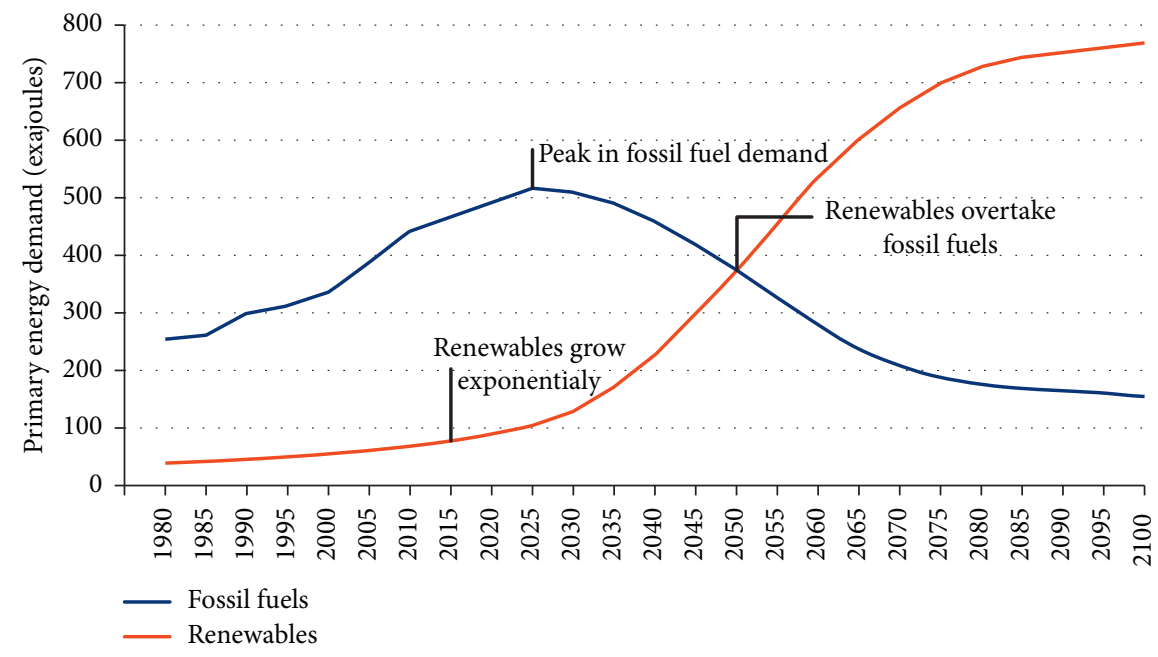

FIGURE 4: Forecasting of the energy transformation projects [6].

Therefore, its new energy story has two sides. Firstly, the US will emerge as a major energy producer and exporter. While this will not reduce American curiosity in a low and stable oil price derived on the global market, it will change the nature of the country's relationship with existing suppliers and new procurers [46]. Secondly, the US may express less interest in bilateral energy and strategic alliances, like its relation with Saudi Arabia and other Middle Eastern countries [45]. While the US is going towards the more isolationist path from its traditional superpower role once it carried out in the last century, there are growing economic countries such as China, India, Brazil, and Russia which are undoubtedly playing an essential role in the geopolitical stage since the beginning of the 21st century specifically in the aftermath of 2008's global financial crisis. With their growing economies, their energy consumption rates are also ascending progressively [39]. Thus, to mitigate their additional demand for energy, they are now seeking alternative energy resources and routes for hassle-free uninterrupted fossil fuel. Apart from these growing economies, several regions such as Central Asia, Arctic region, Eastern Mediterranean, and the South China Sea are offering substantial gas reserves that are attracting growing economies to develop energy cooperation for exploration of those reserves as well as traditional energy suppliers like Saudi Arabia and other emerging countries such as Venezuela, Russia, and 


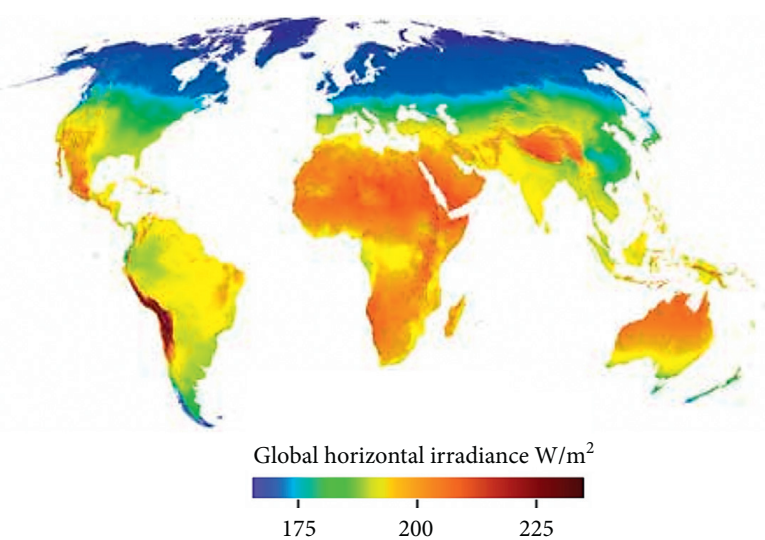

(a)

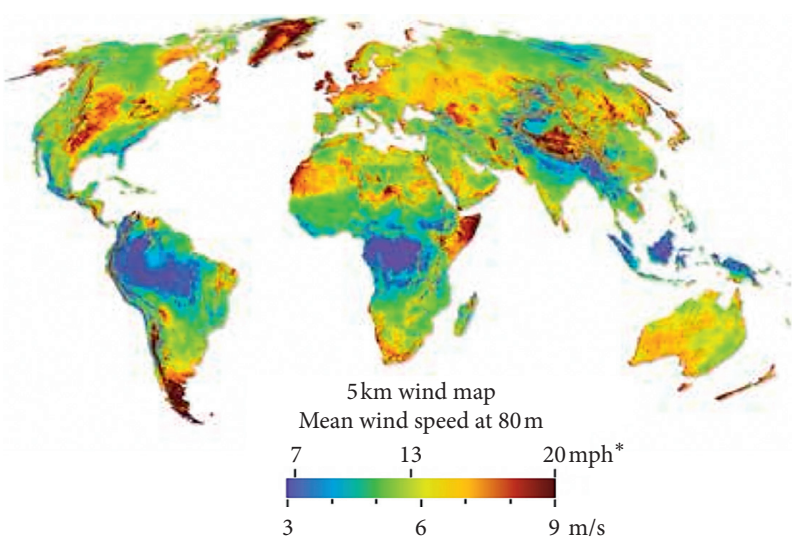

(b)

FIgURE 5: (a) World solar potential [28]. (b) World wind potential [10].

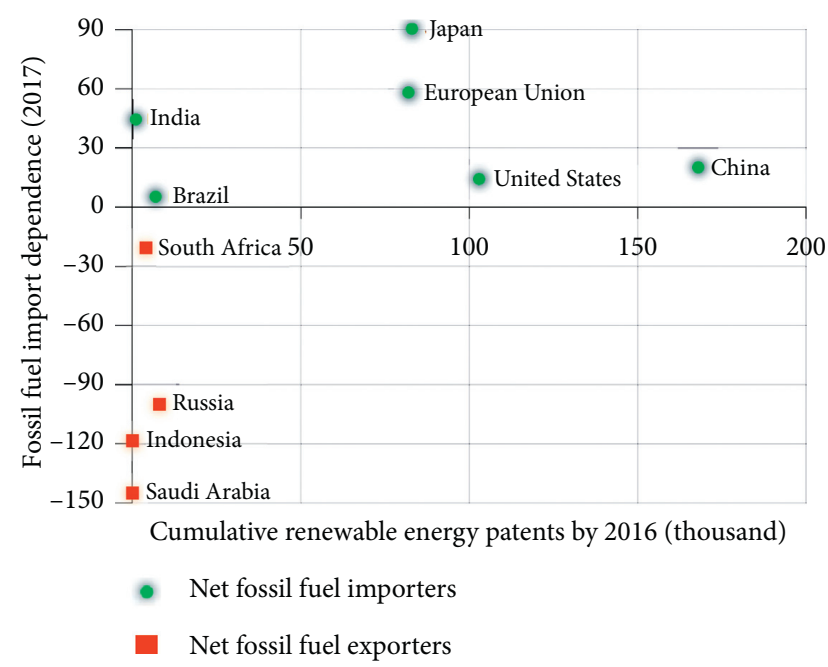

FIGURE 6: Energy transition and its impact on top economies [44].

Iran are attracting global attention [15, 39, 47]. For natural gas, Russia holds the largest reserves, and the country is gaining popularity for processing natural gas to LNG. After Russia, Iran has the 2nd largest natural gas reserve in the world. However, due to international sanctions and unattractive investment framework, Iran failed to be a significant natural gas exporter till now. The country has also proven oil reserves. With oil and gas reserves, it possesses the possibility to become energy superpower together with Russia. Having substantial oil reserves and being popularly known as "petrostate," Venezuela might also contribute in shaping the 21 st century's energy geopolitics if the country can manage to emerge from its recent tailspin [15]. Therefore, along with oil, natural gas tends to play an essential role in the $21 \mathrm{st}$ century's energy geopolitics. Although grease will remain one of the vital energy sources, the importance of natural gas exploration and renewable energy resources is gaining attention increasingly. Hence, the concentration on natural gas and renewable energy generation is promoting the transformation of existing energy order that was on oil in the past century [48]. In this transformation, emerging economies are playing an important role. Of them, China becomes the pioneer country since the country is promoting BRI's energy projects around the world [15]. As the energy order is an important issue, there are two essential questions for the future of the 21st century's energy order. First, will China continue to accept the existing energy order or try to reshape it following its own perceived interests? Second, will the US devote economic and diplomatic capitals necessary to preserve the liberal order it helped to create in the past century? While searching the answers to these questions, it is seen that China is losing its reliance on the existing West-led energy order $[43,48]$. Although the country has a heavy dependence on fossil fuel imports, it tends to expand its dependency on renewable energy. It has a leading position in innovation and deployment of renewable energy technologies. The country is the most significant location for renewable energy investment accounting for over $45 \%$ of the global total in 2017 [46]. Now, it becomes the world's renewable energy superpower. The country is the world's largest producer, exporter, and installer of solar panel, wind turbines, and electric vehicles. Along with natural gas, it is mostly supported that the advent of renewable energy is one of the essential reasons behind the transformation of existing energy order [36]. Renewable energy may reconfigure alliances and create new interdependencies. If global demand for fossil fuel drops, partnerships fabricated on fossil fuels are likely to fade away. Associations may be conserved for other motives, but the energy pillar will become comparatively less vital. Bilateral relations between states will also change $[13,33,45]$.

The alliance between US and Saudi Arabia is a prime example where oil played a key role [15]. Therefore, if renewable energy wins the heart of the consumers, then the global energy dependency will shift from global energy markets to regional power grids. Countries who are importing oil today will seek to develop renewable and integrate power grids with neighboring countries to buy and sell electricity. Regarding this sector, China is the forerunner [16]. Therefore, in transforming the existing energy order and shaping the energy geopolitics of the 21st century, China's mega plan BRI has enormous implications. 
The synergy between energy geopolitics and the BRI is seen as China's latest mega policy has many projects which are fully dedicated to energy cooperation. This cooperation will widely promote new energy producers who can support producing renewable energy and exploration of natural gas and new alternative energy routes that can ensure uninterrupted oil transport. Under this grandiose plan, China is willing to create a global super grid called "Global Energy Interconnection (GEI) [41]." If implemented, this super grid will link every continent to power the world. Since China is trying to decrease its dependency on fossil fuel imports that pass through SLOCs such as the Strait of Malacca and the South China Sea, the country will support the energy evolution starting conventional remnant fuel to renewable dynamism [39].

BRI can play a momentous character in this regard since its massive infrastructure framework will offer all the participating countries to be in the network of power grids, integrated pipelines, and upgraded infrastructures. Therefore, China's infrastructure diplomacy through the BRI is an essential strategy as the protection of sea lanes was to the hegemony of the US in the 20th century. Thus, BRI is going to be the key role player in transforming the existing energy order and shaping the energy geopolitics of the 21st century. This role of BRI is extensively discussed in the results and analysis sections.

\section{Materials and Methods}

The results of this study were analyzed and anticipated using three types of data: (i) qualitative primary data, i.e., previous published literature; (ii) secondary data collected from interviews by adopting expert opinion technique from the academia and infrastructure development professionals, in shape of books and articles; and (iii) data collection from social media, newspapers and electronic media, and web pages. Some of the knowledge-based data has been collected from BRI released documents [49, 50]. In addition, a grounded-theory investigation has been adopted to construct meaning from the data collected through national and international news monitoring, experts' opinion, and indepth interviews that were augmented by the data extracted from the detailed review of the literature. This study was aimed at providing a realistic scenario of the BRI influencing geopolitics of energies. A thematic and knowledge-based approach was adopted to analyze and identify the emerging lessons. This study also argues BRI's involvement for changing the nature of the existing energy order that will gradually shape the future of energy geopolitics for different economic powers.

\section{Results}

4.1. Energy Cooperation under the BRI. Under the BRI, energy infrastructure and transportation projects play a crucial role in fostering more significant trade and investment as well as interconnectivity between China and its neighbors. To do so, China is utilizing the BRI for strengthening energy cooperation along with BRI countries. BRI's energy cooperation strategy revolves around four notable areas: international diversification of oil and gas production, energy-related infrastructure development along with the Belt and Road region, expanding of international energy technology cooperation, and the sustenance of global energy governance, as shown in Figure 7.

This distribution was recapped in the "Vision and Actions on Energy Cooperation" document in May 2017 [33]. Apart from these four broad areas of energy cooperation, this latest "Vision and Actions" document highlighted seven more areas of energy cooperation through BRI. These are unimpeded trade, policy coordination, energy production capacity cooperation, energy investment cooperation, energy infrastructure connectivity, and sustainable energy for all and better governance structure [45]. Based on all these proposed areas of collaboration, China has already started to work on strengthening energy cooperation through several of BRI's energy projects. By reviewing China's current energy projects under the BRI, this section explores how China is promoting energy cooperation along with all BRI countries.

4.2. Development of Energy Infrastructure. Ensuring correct energy needs huge levels of infrastructure development. Owing to this regard, investment in the development of infrastructure is the foundation of BRI. Since energy collaboration is one in every crucial aspects of BRI, it adopts the "Vision and Actions on Energy Cooperation" document [52]. This document includes the areas that are promoting energy assistance for assistant grade open, complete and convenient communal of shared interests, bond and intention; rising regional energy shelter and enhancing the delivery of energy resources; and group action native energy markets and pushing forward inexperienced and low-carbon development $[41,52]$. Hence, energy cooperation below the BRI is often understood as a colossal collaboration of assorted actions among member countries' governments, firms, and people. Moreover, it is also distinguished from the mentioned goals that the proposed energy cooperation will not only ensure the energy security of China but also hugely benefit the member countries. Another important aspect is the objectives of all BRI projects. Many assume that all BRI projects may have underlying political agendas and these projects are purely commercial mainly to benefit China. Therefore, energy projects under BRI have to face these assumptions. Whatever the results these energy projects will bring, at the initial stage, it can be said that if BRI maintains its proposed goals for energy cooperation, it can play an essential role in integrating regional energy market and reducing each member country's energy deficiency $[32,53]$. By now, China is investing for the ten most significant power plant projects under the BRI. Of them, eight power projects are in Pakistan within BRI's one of the critical economic corridors, i.e., China-Pakistan Economic Corridor (CPEC) $[38,47,54]$. Eight power projects that are located in Pakistan under the CPEC are (1) Suki Kinari Hydropower Project, that is being constructed on the Kunhar River in Pakhtunkhwa province and expected to generate 870-megawatt (MW) power; (2) Quaid-e-Azam Solar Park has been under 


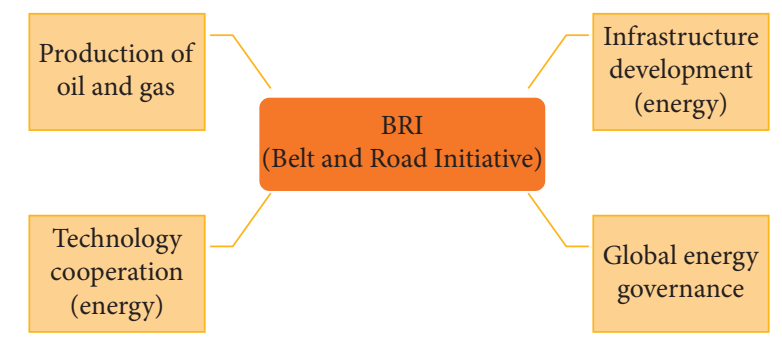

FIGURE 7: Energy cooperation under Belt and Road Initiative (BRI) [51].

construction since 2015 in Bahawalpur region, Punjab, and supposed to generate 1,000 MW power; (3) Kohala Hydel Project is under construction [8, 55-57], Jhelum River, $85 \mathrm{~km}$ east of Islamabad, and is expected to generate 1100 MW power; (4) Thar Mine Mouth Oracle Power Plant is a proposed coal-fired power project in the Thar Block-VI of the Thar coal mines in Sindh province and expected to generate $1320 \mathrm{MW}$ power; (5) SSRL Thar SEC Mine Mouth Power Plant is under construction in the Thar-Block-I region of Sindh and expected to create $1320 \mathrm{MW}$ energy; (6) China Power Hub Generation Company (CPHGC) Power Plant is a coal-fired power project in Hub city, Baluchistan, which is under construction and expected to generate 1320 MW power; (7) Sahiwal coal-fired power plant is operational since 2017 in the Sahiwal region in Punjab producing $1320 \mathrm{MW}$ and connected to Pakistan's national grid in 2019; and (8) Port Qasim Power Project is a coal-based power plant in the Sindh and has been operational since 2018 $[19,32,48,58]$, as shown in Figure 8.

Apart from these eight power projects in Pakistan, one power project named Hassyan clean coal project is under construction since 2016, in the Gulf cooperation council region, Dubai, United Arab Emirates. It is part of Dubai's Integrated Energy Strategy 2030. While Dubai Electricity and Water Authority (DEWA) holds the majority (51 percent) share in the project, ACWA Power holds 26.95 percent, Harbin Electric International Company (HEI) holds 14.7 percent, and Silk Road Fund holds the remaining 7.35 percent. This project will be generating $2400 \mathrm{MW}$ power $[15,18]$. Another power project is the Kayan River cascade hydropower project. It is a multiphase power development in the northern Kalimantan province, Indonesia. It has been under construction since 2010 and is part of Indonesia's comprehensive economic corridor under the BRI. It is expected to generate $9,000 \mathrm{MW}$ power [16].

For strengthening energy supply mechanism, in the "Vision and Actions" document of the BRI [50], it is mentioned that through BRI, China will be trying to enhance and expand the scale of oil and gas pipeline connectivity. For bypassing unstable and insecure chokepoints like the Strait of Malacca and susceptible routes in the disputed South China Sea, China is pursuing to develop new land-based transit routes via responsive countries [54]. Among friendly countries, Pakistan and Myanmar are two important countries with which China is trying to tie up for developing pipeline connectivity. In Myanmar, China has a crude oil and gas pipeline project. The oil pipeline is located in
Kyaukpyu Township in Myanmar's Rakhine state. This project began operating in April 2017. This pipeline runs from Maday Island in Kyaukpyu township in Rakhine state to the city of Ruili in China's southwestern Yunnan province. It can transport 22 million tons of oil annually [45]. Another gas pipeline runs from Ramree Island in Kyaukpyu to China with an annual capacity of up to 12 billion cubic meters $(\mathrm{bcm})$ of natural gas. This crude oil and gas pipeline is supposed to be operated under the proposed China-Myanmar Economic Corridor (CMEC) of BRI [59] as shown in Figure 9. Pakistan and China are managing their CPEC project under which China has an oil pipeline development plan. It was reported in Pakistan in 2016 that the proposed oil pipeline would carry US\$ 1 million barrels per day of Middle Eastern oil to China [15, 37].

In Central Asia, China is also cooperating through the BRI in developing integrated oil and gas pipeline. In this region, Azerbaijan is an important natural gas and oil-rich country. The country has a long aspiration to export its natural gas and oil to Turkey and Europe [61]. Although Europeans made a project named "Nabucco" in 2002 to transport gas from Azerbaijan to Turkey and Southern Europe, it failed due to lack of credit guarantees. In this context, China came to aid this project under its BRI [41]. In 2011, a new pipeline named Trans-Anatolian Pipeline (TANAP) had been introduced. The pipe is supposed to carry Azeri gas to Turkey and connect with the proposed Trans-Adriatic Pipeline (TAP) that would take the gas on to Italy. An essential thing in this newly announced pipeline project is that China is backing the whole project [11]. China's Asia Infrastructure Investment Bank (AIIB) [62] agreed to channel US\$ 600 million to support the TANAP project [37]. This financial support from the AIIB is the most significant investment until now. TANAP is one of two pipelines under the Southern Gas Corridor. In this corridor, another gas pipeline is TAP. BRI is involved in this corridor by backing up TANAP through AIIB. The involvement of AIIB is signaling the spirit of BRI to aid in connecting countries of BRI [63]. The TANAP gas is expected to deliver its first gas to European markets in 2020. Another important aspect of this project is that this pipeline is expected to gas up only European countries, whereas most of the projects under the BRI end up reaching China. Therefore, this project shows the BRI spirit in connecting other countries not only with China but also among themselves $[11,63]$. In Figure 10, it is showing that the Azeri gas is supposed to be carried by TANAP from Azerbaijan's Shah Deniz gas field. This gas will run from Azerbaijan through Georgia and Turkey's 20 provinces and end at the Greek border of the Uppsala district Turkey's Edirne province. From this point, another gas pipeline TAP will carry the gas to other European countries. Initially, the TAP will transport the gas from Greece through Albania to Italy. Through this gas corridor, European countries are trying to improve their energy security by bringing natural gas from the Caspian region and reducing dependency over Russian gas. Among all the pipeline projects under the BRI, Yamal Liquefied Natural Gas (Yamal LNG) project has experienced success since its operation. The Yamal LNG project is located in Russia's Yamal 


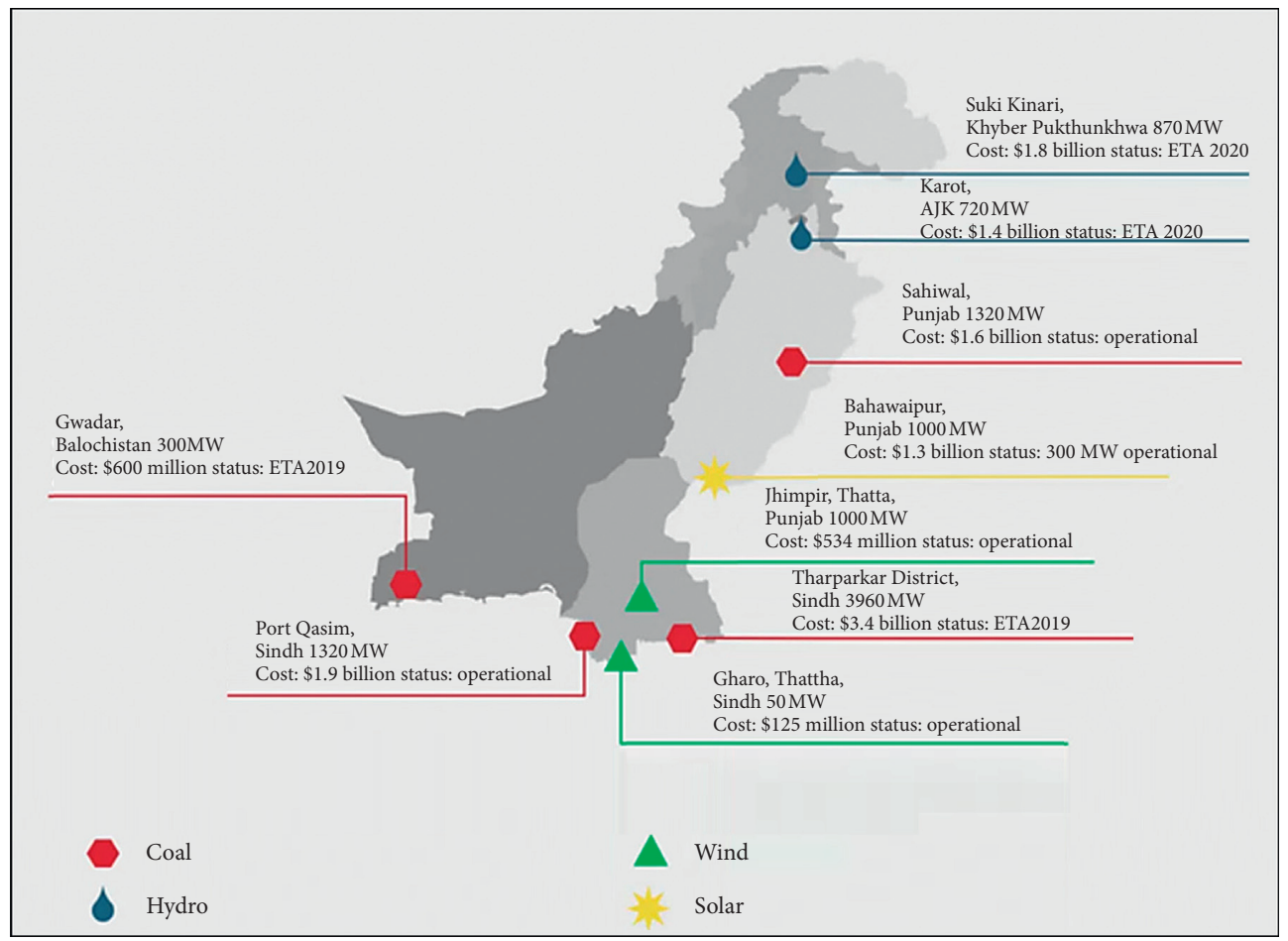

FIgURE 8: Major power projects of CPEC [58].

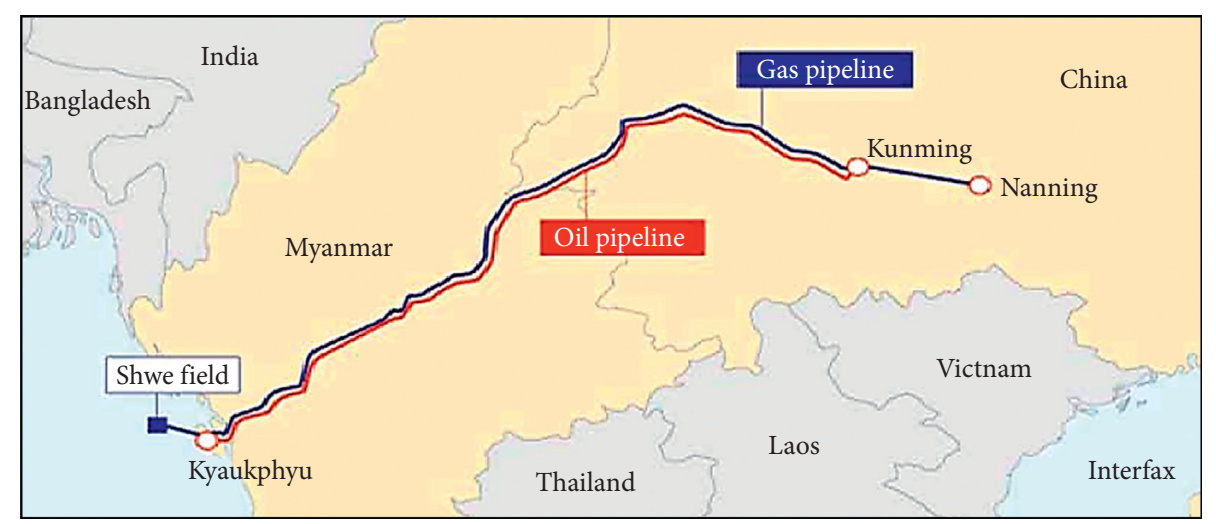

Figure 9: Oil and gas pipeline from Myanmar to China [60].

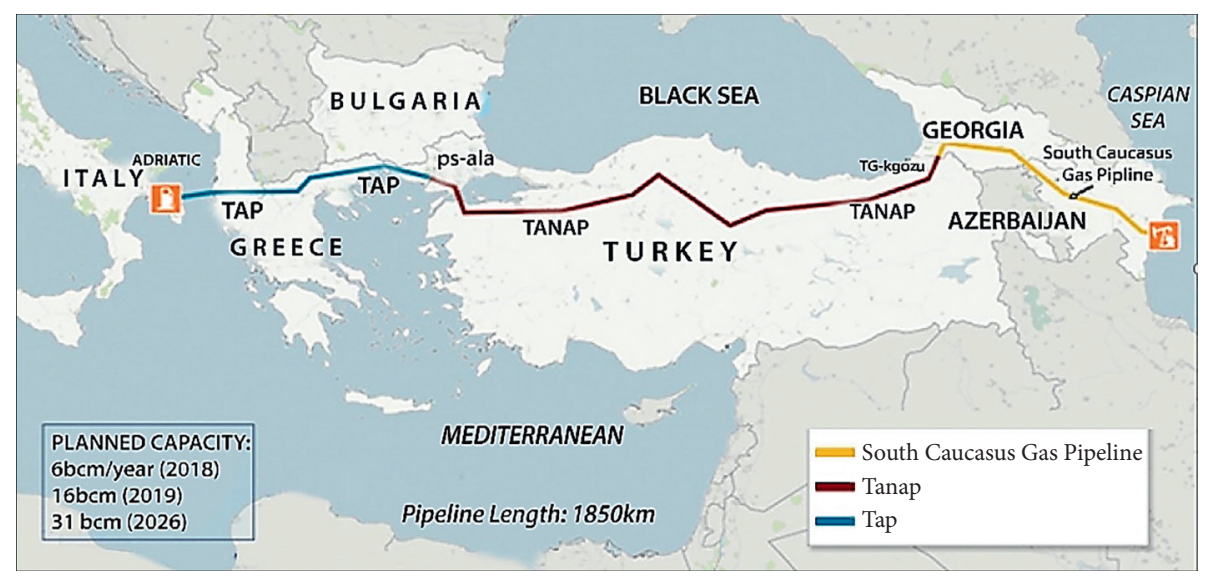

Figure 10: TANAP and TAP pipeline [35]. 
Peninsula in the Arctic. The project reached its full production with its three production lines; each production line has a capacity of 5.5 million tons per year. The production lines' operation started in December 2017, August 2018, and December 2018, respectively [49]. It is the first megaenergy cooperation project in Russia under the BRI. The project is owned by Russia's Novatek (50.1 percent), France's 20 percent, and China's Silk Road Fund 9.9 percent. Apart from financial involvement, Chinese contribution was also in the technical support for this project $[11,54,64]$.

China Off-Shore Oil Engineering Co., Ltd. (COOEC) [65] has an agreement with the Yamal project for manufacturing the Module Fabrication Work Package for this project. By doing this, Chinese engineers gained knowledge of gas production in such a harsh Arctic climatic condition. After successful creation of the Yamal LNG project, it increased BRI's status in the world energy market. Furthermore, the successful launch of this project made prospective involvement of Chinese companies in other Arctic energy projects [13]. The location of Yamal LNG Project also allows half shipping time through the Northern Sea Route compared to the Southern Sea Route. Through the Northern Sea Route, it takes 15 days to reach Asia, whereas it takes 30 days to reach Asia by the traditional Southern Route through the Suez Canal. As one of the shareholders of Yamal LNG, China started importing arctic gas from the project. PetroChina's Jiangsu Rudong LNG terminal is receiving frozen gas from this project. This gas is coming through the Northern Sea Route [66].

Figure 11 shows that through the Northern Sea Route, the LNG shipment from the Yamal LNG project to China is taking half time compared to the traditional Southern Sea Route through the Suez Canal. After the success of this project, China now aims to construct a "Polar Silk Road" or "Ice Silk Road" by developing Arctic shipping routes. These shipping routes seem more viable than shipping through the Suez or Panama canals. In this regard, gas shipment from the Yamal LNG project to China through the Northern Sea Route is increasing China's confidence to develop Ice Silk road along the Arctic [49].

Over the next 20 years, it will be investing more than US\$ 6 trillion in low-carbon power generation and other clean energy technologies [66]. As part of its aspiration to build a "Green Belt and Road," the country is now focusing on green and low-carbon clean energy. As part of this commitment, it is investing in the BRI countries' renewable energy generation projects [49]. In Argentina, China funded for solar power plant. It is a $500 \mathrm{MW}$ solar power plant named Cauchari Solar Power Plant. For this plant, China funded 85 percent of its total expenditure. It is the largest renewable energy project in Latin America. Another major solar power project is situated in Egypt $[66,67]$. China is also funding this project through the AIIB [62]. This project is known as Benban Solar Park. Its capacity is 2 gigawatts. China has also proposed hydropower plant in Mongolia, the Democratic Republic of Congo, and Indonesia [63]. In Turkey, China is also investing in renewable energy generation. In the upcoming years, China is expected to invest around US\$ 600 million in Turkey's renewable energy sector [68]. In UAE,

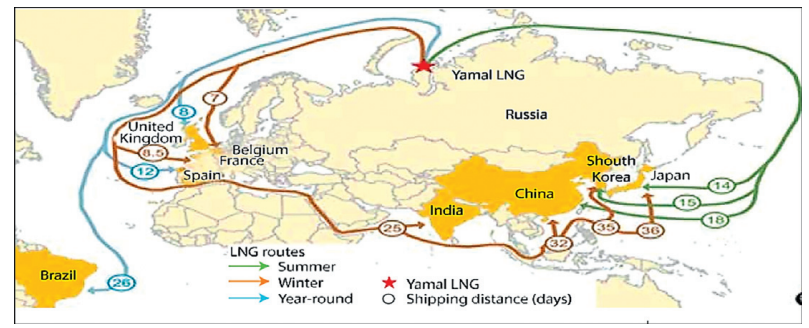

FIgURE 11: Yamal LNG and Arctic route for fuel shipping [66, 67].

China has jointly developed the Sweihan Photovoltaic Independent Power Project. It is a $1,177 \mathrm{MW}$ solar power generation project. It is anticipated that this power plant may generate power for 195,000 homes approximately. By doing so, it can cut seven million tonnes of carbon emissions a year [11]. In Kenya, China is investing in wind power generation. Sinomach and General Electric are jointly building a $102 \mathrm{MW}$ wind power project in Kapedo, Kenya [69]. China is also financing Germany's Meerwind offshore wind farm [70].

4.3. Alternative Energy Routes. Ensuring uninterrupted energy supply is an utmost need for China's massive economy. Therefore, this issue is given high priority in BRI. Since China is still relying heavily on fossil fuel, its fossil fuel shipments are heavily dependent on the Strait of Malacca. The country's 80 percent of oil imports come through this vital choke point [37]. Figure 12 is showing that the distance between the proposed route of Gwadar Port in Baluchistan to the city of Kashgar in Xinjiang is only $2,000 \mathrm{~km}$. In contrast, the existing energy sea route from the Persian Gulf via the Strait of Malacca to Beijing is $12,900 \mathrm{~km}$ which is famously known as China's "Malacca Dilemma" termed by the former Chinese President $\mathrm{Hu}$ Jintao, which means the country's heavy reliance on this single choke point, the Strait of Malacca, is vulnerable to disruption [11,54]. This choke point is China's security concern because it is currently the only route through which China's energy shipments have to pass. Therefore, any confusion or blockade of this choke point can lead to severe energy and trade crises in China [67]. Currently, the US is patrolling the Strait of Malacca choke point, and India has developed a credible naval presence in the Andaman Sea adjacent to this choke point. India is also partnering with the US and other countries for safeguarding this choke point $[23,72]$. Hence, this situation can translate into a threat in any kind of conflict among rival navies. The blockade situation in the Strait of Malacca during any type of conflict may lead to severe political and economic consequences in China [73]. To avoid such disruption, China proposed a new sea route from Gwadar Port to Xinjiang Province. The proposed way is under the CPEC of BRI. Since Pakistan links East Asia, Central Asia, and the Middle East with land routes and sea lines, it allows Gwadar Port to be a hub of trade in BRI. This port is only $2000 \mathrm{~km}$ away from China's Xinjian province. Therefore, the Gwadar port can be a choice for China to avoid oil shipping through the Strait of Malacca [71]. China is also involved with the 


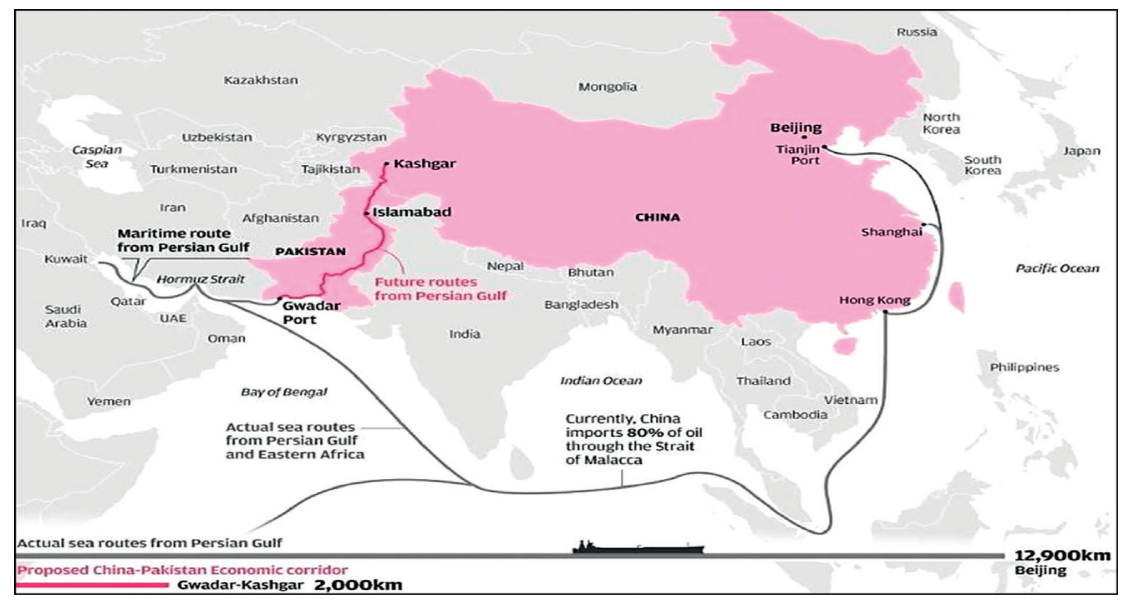

FIGURE 12: China alternative energy route [71].

South China Sea dispute with Brunei, Malaysia, Indonesia, the Philippines, and Vietnam as it is showing in the map that the Chinese oil shipments are passing from the Persian Gulf through the Strait of Malacca via the South China Sea $[49,65,74]$. Therefore, any kind of volatile situation in the South China Sea will also disrupt oil shipment. Currently, Pakistan has two international deep-sea ports, Karachi Port and Port Qasim.

Under the CPEC, China proposed Pakistan to help in building its third deep-sea port called Gwadar Port. It is situated on the shores of the Arabian Sea in the western province of Baluchistan. It is about $533 \mathrm{~km}$ from Karachi and $120 \mathrm{~km}$ from the Iranian border [20]. It is located at the mouth of the Persian Gulf, just outside the Strait of Hormuz, near the vital shipping routes in and out of the Persian Gulf. Although the Gwadar port construction was inaugurated by the Prime Minister Parvez Musharraf in 2005, it was announced in 2015 that the Gwadar Port would be developed under China's CPEC initiative with Pakistan [35]. From the year 2015, construction work in Gwadar Port started. This port city has been officially leased to China for 43 years until 2059. Once this port gets operational, it is expected that China may use a shorter and cheaper route for its oil shipments by circumventing the Strait of Malacca and vulnerable shipping lanes through disputed South China Sea $[10,75]$. By constructing this deep-sea port, China is also creating an alternative route for other countries. Connecting the Arabian Sea to the Eurasian heartland, the port could serve as a transit point for alternative routes between China, Afghanistan, Central Asia, and Middle Eastern countries [75]. Therefore, the Gwadar Port, under the CPEC of the BRI, is going to bring a massive change in the existing energy order as it will usher a new route for oil shipments. Also, China can avoid any potential confrontation with the US in the context of the US increasing existence in the South China Sea, where it is pursuing to magnify its impact as part of its pivot to Asia [37].
4.4. Regional Energy Market and Value Chain Integration. BRI may create opportunities for the regional energy market in the long run. It may drive energy-related industries since numerous energy projects are running under this mega plan, and many more projects are in the pipeline. Energy projects that involve pipeline construction, port development, and power plant construction create markets for construction and machinery industries. Because of various energy projects in multiple countries, BRI may create opportunities for different energy hubs in different regions. These energy hubs will help countries to buy and sell power among themselves. Therefore, in the long run, BRI countries may consider establishing regional energy markets in different regions. For natural gas and electricity, local markets will be developed around pipelines and transmission grids. Moreover, under BRI's energy cooperation, it offers to expand the worth chain in vitality age from customary upstream abuse and investigation of fossil vitality to downstream exercises, for example, pipeline development and petrochemical activities related to sustainable power source improvement [37]. There may be open doors for Chinese endeavors to receive different works on including direct venture, mergers, and acquisitions, opening private associations, and designing obtainment and development contracts. There may be progressively assorted agreement choices, containing the use of joint endeavors and creation of sharing understanding of how can BRI influence the geopolitics of energy.

BRI's numerous successful operational energy projects will have a substantial influence on the shaping of energy geopolitics in the coming days. These projects are transnational and are contributing to both renewable and nonrenewable energy generation. With these projects, BRI is likely to influence the transformation of the international energy order. Its energy principles are supporting the latest trend of international energy order, which is replacing the 20th century's energy order. BRI's energy vision is also likely 
to manipulate the power politics of the Indian Ocean [12]. China is growing its naval engagement and port establishment in the Indian Ocean due to safeguarding its energy security which is also beneficial for BRI countries. However, this situation has misgivings about a Sinocentric regional order. It has raised concern for the US and other Asian powers [37]. Therefore, it is likely to increase strategic rivalry between regional powers.

Another critical influence is that BRI is powering the promotion of new multilateral institutions regarding energy. Hence, in this section, BRI's influence over energy geopolitics has been discussed based on these three angles, i.e., new energy order, power politics in Indian ocean region, and moving towards new multilateralism as shown in Figure 1 (conceptual model).

BRI may create opportunities for the regional energy market in the long run. It may drive energy-related industries since numerous energy projects are running under this mega plan, and many more projects are in the pipeline. Energy projects that involve pipeline construction, port development, and power plant construction create markets for construction and machinery industries. Because of various energy projects in multiple countries, BRI may create opportunities for different energy hubs in different regions. These energy hubs will help countries to buy and sell power among themselves. Therefore, in the long run, BRI countries may consider establishing regional energy markets in different regions. For natural gas and electricity, local markets will be developed around pipelines and transmission grids. Moreover, under BRI's energy cooperation, it offers to expand the worth chain in vitality age from customary upstream abuse and investigation of fossil vitality to downstream exercises, for example, pipeline development and petrochemical activities related with sustainable power source improvement [37]. There may be open doors for Chinese endeavors to receive different works on including direct venture, mergers, and acquisitions, opening private associations, and designing obtainment and development contracts. There may be progressively assorted agreement choices, containing the use of joint endeavors and creation of sharing understanding of how can BRI influence the geopolitics of energy.

BRI's numerous successful operational energy projects will have a substantial influence on the shaping of energy geopolitics in coming days. These projects are transnational and are contributing to both renewable and nonrenewable energy generation. With these projects, BRI is likely to influence the transformation of the international energy order. Its energy principles are supporting the latest trend of international energy order which is replacing the 20th century's energy order. BRI's energy vision is also likely to manipulate the power politics of the Indian Ocean [12]. China is growing its naval engagement and port establishment in the Indian Ocean due to safeguarding its energy security which is also beneficial for BRI countries. However, this situation has misgivings about a Sinocentric regional order. It has raised concern for the US and other Asian powers [37]. Therefore, it is likely to increase strategic rivalry between regional powers. Another critical influence is that
BRI is powering the promotion of new multilateral institutions regarding energy. Hence, in this section, BRI's influence over energy geopolitics has been discussed based on these three angles, i.e., new energy order, power politics in Indian ocean region, and moving towards new multilateralism as shown in Figure 13 (conceptual model).

4.4.1. New Energy Order. With an intense adjustment in international energy supply and demand, the transformation of international energy order is in the making. In this transformation, BRI is supposed to make a significant contribution. It is promoting interaction between producers and consumers and providing new security and economic values to the international energy order. The shift in major players has made the global energy pattern more balanced. This situation helps in elevating the status of consumer countries in the international energy market. In the changing energy order, interactive relations among various actors tend to be equal and fair. A standard, integrated, cooperative, and sustainable international energy security concept and green and low-carbon energy economic values have begun to replace the traditional theories based on the zero-sum game and cost efficiency [15]. BRI is in line with this trend. It promises to provide opportunities for countries and energy companies to expand oil and gas exploration and transportation capacity, enhance technologies, and broaden the scope of new energy applications [46]. Also, there are three critical variables in the analysis of international energy order: structure of power distribution among international energy actors and their mode of interaction, global energy institutions and their code of conduct, and the values of the international energy economy. These variables can be influenced by the energy cooperation under BRI in the coming days because energy cooperation under the BRI promotes the interaction between producer and consumer countries by both boosting production capacity and creating a cooperative mechanism among consumer countries [39]. The principle of upholding justice along with shared interests and new thinking on collective, comprehensive, collaborative, and sustainable security advocated by the BRI energy cooperation will also provide further protection and economic values to the international energy order.

\subsubsection{Power Politics in the Indian Ocean Region. BRI's} network of ports in the Indian Ocean (IO) littoral countries has a significant contribution in shaping the power politics among regional and extraregional powers of IO. Although the BRI aims to unite every littoral state of the IO under the BRI umbrella for shared prosperity, some major states do not take this mega initiative lightly [76]. India, as one of the major powers of the region, did not receive the idea of BRI positively. For both China and India, IO is an essential place for ensuring their energy security. Mainly for uninterrupted energy supply, China is creating a network of ports and pipelines in IO littoral states to avoid heavy reliance over traditional choke points. Through these ports and pipelines, participating countries are also supposed to be benefitted in the long run. If any deadlock arises in the conventional 


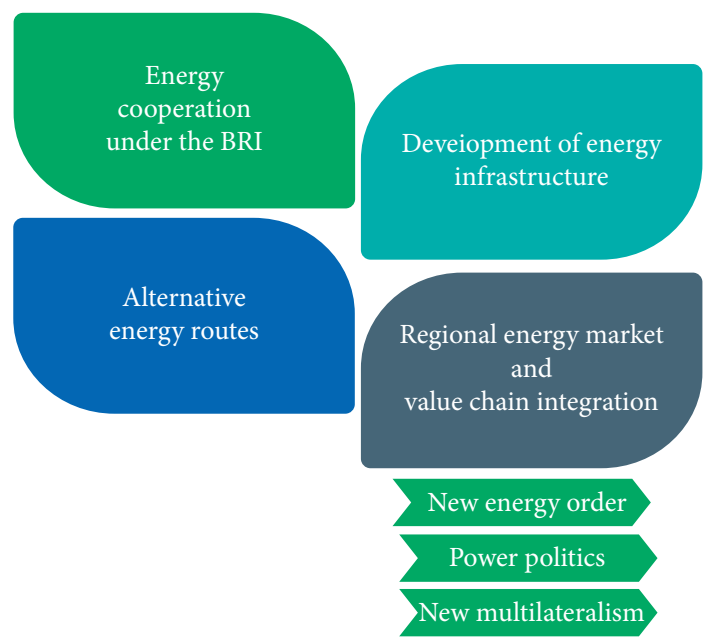

FIgURE 13: Conceptual framework of the study.

chokepoints, namely, the Strait of Malacca and sea lanes in the South China Sea, then China and BRI countries can use alternative energy routes [51]. However, India has discomfort with BRI and is unwelcoming China's port construction for ensuring energy supply lines. Like India, some other neighbors such as Japan and Australia also have discomfiture about BRI. Another critical point is that the current superpower, the US, is also not very comfortable with the Chinese idea of BRI. Due to China's influence over most of the countries through BRI, the US is facing "polar influence" from China [77]. Particularly, BRI's construction of ports, pipelines, and infrastructures is creating concern for IO regional and extraregional powers. Considering security perspectives in the IO in the context of BRI, the Quadrilateral Security Dialogue (QUAD) has been formed by the US, Japan, Australia, and India. This reflects some quarters' suspicious response over BRI [54]. The QUAD is trying to set off the idea of "Free and Open Indo-Pacific" by promoting rules-based order in Asia. Apart from the joint initiative, Quad countries separately showed their responses towards BRI. India in response to BRI introduced "Mausam"-a strategic project aims at reestablishing India's trade and shipping links with IO countries, "Cotton Road"-aims to firm up diplomatic and economic relations with IO countries [51, 77]. With Japan, the Indian Prime Minister Modi agreed to establish the Asia-Africa Growth Corridor (AAGC) to enhance growth and connectivity between Asia and Africa. India is also constructing Chabahar Port in Iran for the betterment of transport and transit connectivity [76]. Russia is also not very comfortable with China and views India as less of a competitor. In response to the BRI, Russia, together with Iran and India, signed an agreement to develop International North-South Transport Corridor (INSTC), which is supposed to be the shortest route to link the IO and the Persian Gulf to the Caspian Sea via Iran and St. Petersburg [78]. Therefore, BRI is attractive to some countries since it offers incentives of trade, connectivity, and infrastructure development. Others, primarily regional powers and the US, have resisted it directly or indirectly due to varying degrees of fear of increased competition. This situation makes the IO a growing area of competition, especially between two regional powers, India and China [76]. To have primacy over regional influence, local authorities are playing power politics to have dominance. In this sense, BRI is fueling this power play in the IO, although its aim is not to create any competition rather than aiding in the development.

4.4.3. Moving towards New Multilateralism. With its numerous energy projects, BRI is promoting a platform for energy cooperation which is ultimately leading to new multilateralism in the energy sector. China is no longer relying on the existing West-led energy order. Therefore, the country is trying to stimulate new energy order by promoting energy cooperation under BRI. This energy cooperation involves numerous transnational energy projects. Due to these cross-border energy projects, Chinese overseas investments are also increasing day by day. Although China, through its BRI, is operating trillion dollars' worth of energy projects in BRI countries, there is still a lack of an apposite transnational lawful outline for the preservation its foreign energy reserves $[1,79]$. In both regional and global levels, well-structured energy governance will help in the efficacious implementation of the BRI. If there is any kind of trade disputes or cross-border transportation problem, then China and its BRI members will need an authorized body to resolve these problems. BRI countries lack a transnational legal framework. Chinese enterprises that are closely linked with BRI's energy projects have already started raising the issue of dispute settlement [47].

In this context, since China is trying to avoid its reliance over West-led multilateral institutions for energy governance, the country launched BREP during the second Belt and Road Energy Forum in 2019 [79, 80]. BREP may act as similar to the International Energy Agency (IEA). It may follow an energy charter like the IEA. China also established several other multilateral institutions such as the Asian Infrastructure Investment Bank (AIIB) [62], the Silk Road Fund [77], the Shanghai Cooperation Organization [41], and the South-South Cooperation Fund on Climate Change [64]. These multilateral institutions are also directly or indirectly supporting BRI's energy projects. Specifically, the AIIB is directly funding many BRI energy projects. Therefore, through energy cooperation under BRI, China is promoting multilateralism by establishing the BREP and other financial multilateral development institutions. These multilateral institutions will surely have a definite impact on shaping the energy order and energy governance.

\section{Conclusion}

China's BRI is offering a massive amount of opportunities for investment and infrastructure development in the energy and construction sector. Since energy got one of the highest priorities in BRI, the country is expanding its overseas energy projects gradually. Although securing its energy demand is one of the main interests of China to expand its energy footprints overseas through BRI, this will be mainly beneficial to all BRI countries. Under BRI energy projects, 
China is trying to diversify energy source passage means away from traditional choke points and susceptible sea lanes. These alternative routes are supposed to be beneficial to all BRI countries in any sudden blockade situation in traditional choke points. Energy cooperation among BRI countries is strengthening progressively with these alternative routes, newly developed shipping lanes, and newly constructed ports and pipelines. BRI's energy projects are also likely to influence shaping the new energy order. Since the BRI is aiding the new energy powers by funding their energy projects, promoting renewable energy generation and promoting multilateral institutions to support energy governance, this mega plan is gradually contributing to shaping the new energy order. Through its massive contribution to the energy sector, essential variables of the energy order are likely to be influenced to a great extent. These variables are the structure of power distribution among international energy actors and their mode of interaction, international energy institutions and their code of conduct, and the values of the international energy economy. Energy cooperation under BRI promotes the communication between producer and consumer countries by both boosting production capacity and creating a cooperative mechanism among consumer countries. BRI energy cooperation supports the principle of upholding justice along with shared interests and new thinking on collective, comprehensive, collaborative, and sustainable security. Therefore, this energy cooperation under BRI may provide further protection and economic values to the international energy order.

In closing, although the BRI offers a holistic approach to connect countries, furthermore, regions for getting benefits from developed infrastructure, integrated trade facilities, sustainable energy as well as shared prosperity for all, it creates confusion to some regional and extraregional stakeholders. Along with constructing ports and pipelines to develop the energy infrastructure, China is also increasing its naval engagement in the Indian Ocean to protect and safeguard its energy infrastructure. However, these developments are creating concerns for the US and other regional powers. Mainly, India is not comfortable with BRI's energy projects throughout the Indian Ocean. In this context, if China successfully manages to avoid power rivalry and accommodate new energy powers, then BRI's energy projects can provide the full benefit. Since the BRI conforms with the latest trend of energy generation, it will make the international energy structure more balanced. Once the energy structure becomes stable, it will create credible patterns of interaction between buyer and seller. This will in the long run establish new energy values and shape the geopolitics of energy.

\section{Data Availability}

The data used to support the findings of this study are included in the article.

\section{Conflicts of Interest}

The authors declare that they have no conflicts of interest regarding the publication of this paper.

\section{Acknowledgments}

This research was fully funded by the Northeast Asian Research Centre, Jilin University, China.

\section{References}

[1] M. M. A. Khater, D. Lu, and R. A. M. Attia, "Dispersive long wave of nonlinear fractional Wu-Zhang system via a modified auxiliary equation method," AIP Advances, vol. 9, no. 2, p. 25003, 2019.

[2] D. Lu, A. R. Seadawy, and M. M. A. Khater, "Structure of solitary wave solutions of the nonlinear complex fractional generalized Zakharov dynamical system," Advances in Difference Equations, vol. 2018, no. 1, 2018.

[3] J. Li, Y. Qiu, D. Lu, R. Attia, and M. Khater, "Study on the solitary wave solutions of the ionic currents on microtubules equation by using the modified Khater method," Thermal Science, vol. 23, no. 6, pp. 2053-2062, 2019.

[4] B. Buzan and O. Wæver, "Macrosecuritisation and security constellations: reconsidering scale in securitisation theory," Review of International Studies, vol. 35, no. 2, pp. 253-276, 2009.

[5] Y. Hong, "Reading the 13th five-year Plan: reflections on China's ICT policy," International Journal of Communication, vol. 11, pp. 1755-1774, 2017.

[6] M. A. Khwaja, S. Saeed, and M. Urooj, Preliminary Environmental Impact Assessment (EIA) Study of China-Pakistan Economic Corridor (CPEC) Northern Route Road Construction Activities in Khyber Pakhtunkhwa (KPK), Pakistan, Sustainable Development Policy Institute, Islamabad, Pakistan, 2018.

[7] M. Nilofar, W. S. Jiang, and M. Ishtiaque, "The growing economic ties between Pakistan and China and its impact on the economy of Pakistan," IMPACT: International Journal of Research in Humanities, Arts and Literature, vol. 2, pp. 49-54, 2014.

[8] T. J. Yamada, D. Takeuchi, M. A. Farukh, and Y. Kitano, "Climatological characteristics of heavy rainfall in northern Pakistan and atmospheric blocking over western Russia," Journal of Climate, vol. 29, no. 21, pp. 7743-7754, 2016.

[9] C. Y. J. Peng, T. S. H. So, F. K. Stage, and E. P. St. John, "The use and interpretation of logistic regression in higher education journals: 1988-1999," Research in Higher Education, vol. 43, no. 3, pp. 259-293, 2002.

[10] G. Abbas, Z. Liu, S. H. Wasti, U. Munir, and M. Abbas, "CPEC's utility and concerns under OBOR initiative: a Pakistani industrial perspective," Economies, vol. 7, no. 3, p. 90, 2019.

[11] D. Acemoglu, "Introduction to economic growth," Journal of Economic Theory, vol. 147, no. 2, pp. 545-550, 2012.

[12] L. Naz, A. Ali, and A. Fatima, "International competitiveness and ex-ante treatment effects of CPEC on household welfare in Pakistan," International Journal of Development Issues, vol. 17, no. 2, 2018. 
[13] H. E. Daly, "Toward some operational principles of sustainable development," Ecological Economics, vol. 2, no. 1, pp. 1-6, 1990.

[14] A. Saad, G. Xinping, and M. Ijaz, "China-Pakistan economic corridor and its influence on perceived economic and social goals: implications for social policy makers," Sustainability, vol. 11, no. 18, p. 4949, 2019.

[15] R. Dossani, J. Bouey, and K. Zhu, Demystifying the Belt and Road Initiative, RAND Corporation, Santa Monica, CA, USA, 2020.

[16] R. Ahmed and U. Mustafa, "Impact of CPEC projects on agriculture sector of Pakistan: infrastructure and agricultural output linkages," in Proceedings of the Annual General Meeting of Pakistan Society of Development Economics, pp. 511-527, Islamabad, Pakistan, 2016.

[17] G. Nabi, S. Ullah, S. Khan, S. Ahmad, and S. Kumar, "ChinaPakistan economic corridor (CPEC): melting glaciers-a potential threat to ecosystem and biodiversity," Environmental Science and Pollution Research, vol. 25, no. 4, pp. 3209-3210, 2018.

[18] J. N. Whitman, An Analysis of the Primary Driver for China's Belt and Road Initiative-Security versus Economics, Naval Postgraduate School Monterey United States, Monterey, CA, USA, 2018.

[19] Y. Ali, Z. Rasheed, N. Muhammad, and S. Yousaf, "Energy optimization in the wake of China Pakistan economic corridor (CPEC)," Journal of Control and Decision, vol. 5, no. 2, pp. 129-147, 2018.

[20] M. Awais, T. Samin, M. A. Gulzar, and J. Hwang, "The sustainable development of the China Pakistan economic corridor: synergy among economic, social, and environmental sustainability," Sustainability, vol. 11, no. 24, p. 7044, 2019.

[21] R. Menhas, S. Mahmood, P. Tanchangya, M. N. Safdar, and S. Hussain, "Sustainable development under belt and road initiative: a case study of China-Pakistan economic corridor's socio-economic impact on Pakistan," Sustainability, vol. 11, no. 21 , p. $6143,2019$.

[22] W. Ali, L. Gang, and M. Raza, "China-Pakistan economic corridor: current developments and future prospect for regional Integration," International Journal of Research, vol. 3, no. 10, 2016.

[23] T. Jinchen, "One belt and one road: connecting China and the world," Global Infrastructure Initiative, https://www. burmalibrary.org/sites/burmalibrary.org/files/obl/2017-0419-One-Belt-and-One-Road_Connecting-China-and-theworld-en-red.pdf, 2016.

[24] M. Fujita, P. R. Krugman, and A. Venables, The Spatial Economy: Cities, Regions, and International Trade, MIT Press, Cambridge, MA, USA, 1999.

[25] R. Robertson, The Three Waves of Globalization: A History of a Developing Global Consciousness, Zed Books, London, UK, 2003.

[26] D. Z. Zeng, Global Experiences with Special Economic Zones: Focus on China and Africa, The World Bank, Washington, DC, USA, 2015.

[27] L. Wang, Opportunities and Challenges of the China-Pakistan Economic Corridor (CPEC) and Implications for US Policy and Pakistan, East-West Center, Washington, DC, USA, 2017.

[28] M. Khurshid, A. Rashid, and R. M. A. Zahid, "Impact of CPEC energy projects on socio-economic development of Pakistan," in Proceedings of the International Conference on Renewable, Applied and New Energy Technologies, Islamabad, Pakistan, 2018.
[29] M. F. Iqbal and H. Athar, "Validation of satellite based precipitation over diverse topography of Pakistan," Atmospheric Research, vol. 201, pp. 247-260, 2018.

[30] K. M. Butt and A. A. Butt, "Impact of CPEC on regional and extra-regional actors," Journal of Political Science, vol. 33, p. 23, 2015.

[31] A. A. Shah, D. D. Wu, V. Korotkov, and G. Jabeen, "Do commercial banks benefited from the belt and road initiative? A three-stage DEA-tobit-NN analysis," IEEE Access, vol. 7, pp. 37936-37949, 2019.

[32] M. S. B. Khetran and M. A. Saeed, "The CPEC and ChinaPakistan relations: a case study on Balochistan," China Quarterly of International Strategic Studies, vol. 3, no. 3, pp. 447-461, 2017.

[33] K. M. Alam, X. Li, and S. Baig, "Impact of transport cost and travel time on trade under China-Pakistan economic corridor (CPEC)," Journal of Advanced Transportation, vol. 2019, Article ID 7178507, 16 pages, 2019.

[34] M. Nazir, "Analysis of determinants for CPEC's success and failure: emerging challenges and lessons for Pakistan," Development, vol. 6, pp. 200-207, 2015.

[35] G. Nabi, S. Khan, S. Ahmad, A. Khan, and R. Siddique, "China-Pakistan Economic Corridor (CPEC): an alarming threat to the biodiversity of Northern Pakistan," Biodiversity and Conservation, vol. 26, no. 12, pp. 3003-3004, 2017.

[36] F. Vélez, "Do Suez ao Canal do Panamá e além: a influência de Gamal Abdel Nasser na América Latina," Varia Historia, vol. 31, no. 55, pp. 163-191, 2015.

[37] M. Chaziza, "China-Pakistan relationship: a game-changer for the middle east?" Contemporary Review of the Middle East, vol. 3, no. 2, pp. 147-161, 2016.

[38] S. Baig, M. Qasim, L. Xuemei, and K. M. Alam, "Is the ChinaPakistan economic corridor an opportunity or a threat for small and micro-entrepreneurs? Empirical evidence from Northern Pakistan," Sustainability, vol. 12, no. 5, p. 1727, 2020.

[39] H. Hao, Y. Geng, W. Li, and B. Guo, "Energy consumption and GHG emissions from China's freight transport sector: scenarios through 2050," Energy Policy, vol. 85, pp. 94-101, 2015.

[40] S. Scenerio, "Sky scenario," 2020, https://www.shell.com/investors/ environmental-social-and-governance/esg-news-presentationsand-annual-briefings/_jcr_content/par/tabbedcontent/tab_ 667142067/textimage_1262076677.stream/1554190488440/ 9eb8d9c022e6d6b0f6ec20ca12af6f83783e5c9f/sky-scenarioqu.

[41] S. K. Coulibaly, C. Erbao, and T. Metuge Mekongcho, "Economic globalization, entrepreneurship, and development," Technological Forecasting and Social Change, vol. 127, pp. 271-280, 2018.

[42] H. E. Daly, "Allocation, distribution, and scale: towards an economics that is efficient, just, and sustainable," Ecological Economics, vol. 6, no. 3, pp. 185-193, 1992.

[43] J. S. Mill, Principles of Political Economy, Vol. 1, Longman, London, UK, 1900.

[44] M. S. Irshad, Q. Xin, and H. Arshad, "One belt and one road: dose China-Pakistan economic corridor benefit for Pakistan's economy?" Journal of Economics and Sustainable Development, vol. 6, 2015.

[45] M. Yu, "Research on the impact of infrastructure construction on tourism industry: evidence from the "Wuhan-Guangzhou high-speed rail"," Open Journal of Social Sciences, vol. 4, no. 1, pp. 126-131, 2016. 
[46] W. Lin, B. Chen, L. Xie, and H. Pan, "Estimating energy consumption of transport modes in China using DEA," Sustainability, vol. 7, no. 4, pp. 4225-4239, 2015.

[47] M. Ahmar, "Strategic meaning of the China-Pakistan economic corridor," Journal of Strategic Studies, vol. 34, pp. 35-49, 2014.

[48] M. Chowdhary, China's Billion-Dollar Gateway to the Subcontinent: Pakistan May Be Opening a Door it Cannot Close, Forbes, Jersey City, NJ, USA, 2015.

[49] B. Russia, "Green belt \& road initiative center," 2020, https:// green-bri.org/bri-country-perspectives-russia.

[50] B. Initiative, and R. BRI Projects, https://www.beltroadinitiative.com/projects/, 2020.

[51] B. Chakma, "The BRI and India's neighbourhood," Strategic Analysis, vol. 43, no. 3, pp. 183-186, 2019.

[52] F. Shaikh, Q. Ji, and Y. Fan, "Prospects of Pakistan-China energy and economic corridor," Renewable and Sustainable Energy Reviews, vol. 59, pp. 253-263, 2016.

[53] I. Ahmad, J. Oláh, J. Popp, and D. Máté, “Does business group affiliation matter for superior performance? Evidence from Pakistan," Sustainability, vol. 10, no. 9, p. 3060, 2018.

[54] M. I. Chawla, "One belt one road summit 2017 and its implications for CPEC: an overview," Journal of South Asian Studies, vol. 32, pp. 277-284, 2017.

[55] T. Zimmerman, The New Silk Roads: China, the US, and the Future of Central Asia, Center on International Cooperation, New York, NY, USA, 2015.

[56] A. E. Rafi, "Completion of CPEC: impact on Pakistan's strategic position and economy," International Food Policy Research Institute, vol. 2, 2016.

[57] A. Ranjan, "The China-Pakistan economic corridor: India's options," Institute of Chinese Studies, vol. 10, pp. 1-25, 2015.

[58] G. Central, "Implication of the developement of the power projects in Pakistan under CPEC," 2020, https:// gwadarcentral.com/implications-of-the-development-ofpower-projects-in-pakistan-under-cpec/.

[59] A. Dispatches, "The China-Myanmar economic corridor and China's determination," 2020, https:/www.wilsoncenter.org/ blog-post/china-myanmar-economic-corridor-and-chinas-de termination-see-it-through.

[60] X. Chen, "Globalisation redux: can China's inside-out strategy catalyse economic development and integration across its Asian borderlands and beyond?" Cambridge Journal of Regions, Economy and Society, vol. 11, no. 1, pp. 35-58, 2018.

[61] B. Babayev and F. Ismailzade, Azerbaijan's Contribution to the Chinese Belt \& Road Initiative, University Library of Munich, Munich, Germany, 2020.

[62] AIIB Asian Infrastructure Inverstment Bank, https://www.aiib. org/en/news-events/news/2020/Waste-to-Energy-Project-inMaldives-Gets-AIIB-Support.html, 2020.

[63] T. A. Pipeline, "TANAP and TAP complete pipeline connection," 2020, https://www.tap-ag.com/news-and-events/ 2018/11/27/tanap-and-tap-complete-pipeline-connection.

[64] S. A. Ali, J. Haider, M. Ali, S. I. Ali, and X. Ming, "Emerging tourism between Pakistan and China: tourism opportunities via China-Pakistan economic corridor abstract, background: the China-Pakistan economic corridor (CPEC) is a megaproject worth more than 54 billion US dollars, as a result of which bilater," International Business Research, vol. 10, no. 8, pp. 204-214, 2017.

[65] COOCE China Offshore Oil Engineering Co, http:// cnoocengineering.com/en/, 2020.

[66] C. Savard, A. Nikulina, C. Mécemmène, and E. Mokhova, "The electrification of ships using the northern sea route: an approach," Journal of Open Innovation: Technology, Market, and Complexity, vol. 6, no. 1, p. 13, 2020.

[67] C. Dialogue, “Arctic gas plant threatens native peoples," 2020, https://chinadialogue.net/en/energy/10551-arctic-gas-plantthreatens-native-peoples/.

[68] Middle East institute China's belt and road initiative (BRI) and Turkey's Middle corridor: "win-win cooperation"? https://www.mei.edu/, 2020.

[69] M. S. Farooq, T. Yuan, J. Zhu, and N. Feroze, "Kenya and the 21st century Maritime silk road: implications for China-Africa relations," China Quarterly of International Strategic Studies, vol. 4, no. 3, pp. 401-418, 2018.

[70] Reuters China Three Gorges to buy German wind park Meerwind from Blackstone, https://www.reuters.com/article/ us-blackstone-group-wind-farm-china-threidUSKCNOYZ1DC, 2020.

[71] B. P. Review, "The Malacca Dilemma: a hindrance to Chinese ambitions in the 21st century," 2020, https://bpr.berkeley.edu/2019/ 08/26/the-malacca-dilemma-a-hindrance-to-chinese-ambitions-inthe-21st-century/.

[72] E. Waite, "Xinjiang—China's muslim far northwest," Inner Asia, vol. 6, no. 2, pp. 253-255, 2004.

[73] F. Nawaz, M. F. Azam, and N. Noor, "The Dilemma of gadoon amazai industrial estate, Khyber Pakhtunkhwa," Journal of Economics and Sustainable Development, vol. 6, no. 9, pp. 313-327, 2015.

[74] A. Small, The China Pakistan Axis: Asia's New Geopolitics, Random House Publishers India Pvt Limited, Gurgaon, India, 2015.

[75] L. Ali, J. Mi, M. Shah, S. J. Shah, S. khan, and K. BiBi, “The potential socio-economic impact of China Pakistan economic corridor," Asian Development Policy Review, vol. 5, no. 4, pp. 191-198, 2017.

[76] X. Ruan, Y. M. Bandara, J.-Y. Lee, P. T.-W. Lee, and P. Chhetri, "Impacts of the Belt and Road Initiative in the Indian subcontinent under future port development scenarios," Maritime Policy \& Management, vol. 46, no. 8, pp. 905-919, 2019.

[77] C. Wagner and S. Tripathi, India's Response to the Chinese Belt and Road Initiative: New Partners and New Formats, https://www.ssoar.info/ssoar/bitstream/handle/document/ 56213/ssoar-2018-wagner_et_al-Indias_response_to_the_ Chinese.pdf? sequence $=1$ \&isAllowed $=y \& \ln k$ name $=$ ssoar 2018-wagner_et_al-Indias_response_to_the_Chinese.pdf, 2018.

[78] GICA recent developments and trends in international Maritime transport affecting trade of developing countries, http://unctad. org/en/pages/MeetingDetails.aspx?meetingid=205, 2020.

[79] L. Qian, R. A. M. Attia, Y. Qiu, D. Lu, and M. M. A. Khater, "The shock peakon wave solutions of the general DegasperisProcesi equation," International Journal of Modern Physics B, vol. 33, no. 29, p. 1950351, 2019.

[80] C. Park, M. M. A. Khater, R. A. M. Attia, W. Alharbi, and S. S. Alodhaibi, "An explicit plethora of solution for the fractional nonlinear model of the low-pass electrical transmission lines via Atangana-Baleanu derivative operator," Alexandria Engineering Journal, vol. 59, no. 3, 2020. 